\title{
Rainfall Analysis for Hyderabad and Nawabshah, Sindh, Pakistan
}

\author{
Ali Asghar Mahessar \\ Sindh Barrages Improvement Project \\ Sindh Irrigation Department \\ Karachi, Sindh Pakistan
}

\section{Bushra Sadiqui}

Institute of Water Resources Engineering and Management

Mehran University of Engineering and Technology

Jamshoro, Sindh, Pakistan

\author{
Kishan Chand Mukwana \\ Environmental and Energy Department \\ QUEST \\ Nawabshah, Pakistan
}

\author{
Abdul Latif Qureshi \\ U.S.-Pakistan Centers for Advanced Studies in Water \\ Mehran University of Engineering and Technology \\ Jamshoro, Sindh, Pakistan \\ Shafi Muhammad Kori \\ Department of Civil Engineering \\ Mehran University of Engineering and Technology \\ Jamshoro, Sindh, Pakistan \\ Abdul Sami Qureshi \\ Mehran University of Engineering and Technology \\ SZAB Campus \\ Khairpur Mirs, Sindh Pakistan
}

\author{
Khalifa Qasim Leghari \\ Department of Civil Engineering \\ Mehran University of Engineering and Technology \\ Jamshoro, Sindh, Pakistan
}

\begin{abstract}
The climatic change has a visible impact in recent abnormal weather events, such as Pakistan's intensification of the hydrological cycle with changing precipitation pattern, water availability periods, and weather-induced natural disasters. The rainfall flush flood of $\mathbf{2 0 1 0}$ alone displaced milliono of people and damaged properties in just one stroke. The next year, the shocking rainfall flood of 2011 in Sindh, only underscored the enormity of the challenge posed by climate change. The current paper presents the analysis carried out for one-day annual maximum rainfall for Hyderabad and Nawabshah cities, Sindh, Pakistan for the period from 1961 to 2011 using STATISTICA Software for interpolating and forecasting the rainfall time series. The maximum values of observed rainfall were $250.70 \mathrm{~mm}$ and $256.30 \mathrm{~mm}$, while the minimum values were $3.0 \mathrm{~mm}$ and $0.0 \mathrm{~mm}$ for Hyderabad and Nawabshah respectively, while the mean of fifty-one (51) years of rainfall data is $51.96 \mathrm{~mm}$ and $45.3 \mathrm{~mm}$ and the computed standard deviations were $42.693 \mathrm{~mm}$ and $43.896 \mathrm{~mm}$ respectively. The difference between the mean and standard deviation of one-day maximum rainfall is small, which showed the consistency of the data. The polynomial trend curved lines exhibited fluctuations in the rainfall data, which indicates a continual change in rainfall behavior. Hence, the rainfall data are subjected to a moving mean smoothing with a duration shorter than 3 years. Through these trends, the future one-day annual maximum rainfall can be predicted. The correlation of one-day annual maximum rainfall between Hyderabad and Nawabshah cities had $R 2$ of 0.973 . The computed results of return periods of
\end{abstract}

Corresponding author: A. A. Mahessar (amahessar@yahoo.com)
3,5 , and 10 years for one-day annual maximum rainfall for both cities revealed that the rainfall values for Hyderabad are higher.

Keywords-rainfall; Hyderabad; Nawabshah; STATISTICA; GIS

\section{INTRODUCTION}

The equilibrium of heat absorption and reflection from the earth is of paramount importance. Changes in global temperature delicate heat unbalance and are the crucial factor for climate change. The overexploitation of resources has modified the earth and its atmosphere in a way that alters the climate of the globe. Climate variables such as precipitation, temperature, humidity, and wind reach extreme conditions, hence, rainfall occurs abnormally [1-2]. Any change in global climate has massive impacts to humanity and the environment [3]. Rainfall variability rests on the movement of the atmosphere and its characteristics which are described as weather. Scientists have been trying to characterize the weather for several decades [4]. Water is a basic substance, required for the survival of life. Normal precipitation is a part of the continuous process of the hydrologic cycle. The summer rainfall concentrates monsoon breaths formed from the bay of Bengal and arriving Pakistan from India. Another mechanism of monsoon precipitation is the flow of moisture from the Arabian Sea. These phenomena strengthen the rainfall process and produce erratic intensity rainfalls in a short time $[5,6]$. The seasonal unusual rainfall of July to September, 2011 over 
Pakistan, was $72 \%$ above normal (1961 to 1990$)$ and is ranked as the fifth monsoon rainfall during the last 51 years. This seasonal rainfall was about $248 \%$ above the normal in Sindh province [7]. Based on 30 years of meteorological data, Pakistan can be climatically divided into eight zones [8]. Nawabshah comes in a zone of hot long summers and warm short winters, whereas Hyderabad comes in the zone of hot long summers and mild short winters [9]. Extraordinary heavy rainfall and cloud burst alarm about the change in climate. It is quite clear that the cities under study (i.e. Hyderabad and Nawabshah) are under unreliable rainfall zones, which shows an alarming change in climate which needs to be studied [10].

\section{STUDY AREA AND CLIMATIC CONDITIONS}

The two studied cities (Hyderabad and Nawabshah) are located at $25^{\circ} 22^{\prime} 45^{\prime \prime} \mathrm{N}$ latitude and $68^{\circ} 22^{\prime} 06^{\prime \prime} \mathrm{E}$ longitude and at $26^{\circ} 15^{\prime} 00^{\prime \prime} \mathrm{N}$ latitude and $68^{\circ} 25^{\prime} 25^{\prime \prime} \mathrm{E}$ longitude respectively. They are heavily populated, with no rainwater disposal drainage system, and are located at the center of Sindh, on the left side of river Indus [11-13]. Climatically, these cities are situated in tropical and semi-tropical condition with the maximum and minimum temperatures varying from $46^{\circ} \mathrm{C}$, to $02^{\circ} \mathrm{C}$, in Hyderabad and from $52^{\circ} \mathrm{C}$, to $0^{\circ} \mathrm{C}$, in Nawabshah. The mean monthly maximum temperature in the summer season is about $43^{\circ} \mathrm{C}$ to $44^{\circ} \mathrm{C}$, while during the winter, the minimum temperature is about $7^{\circ} \mathrm{C}$. Western disturbances, dust storms, south east monsoon, and continental air are the main factors influencing the weather. From the hydrological perspective, the study areas belong to the arid and semi-arid region type, with a low precipitation average of $100 \mathrm{~mm}$ and brackish and saline groundwater quality.

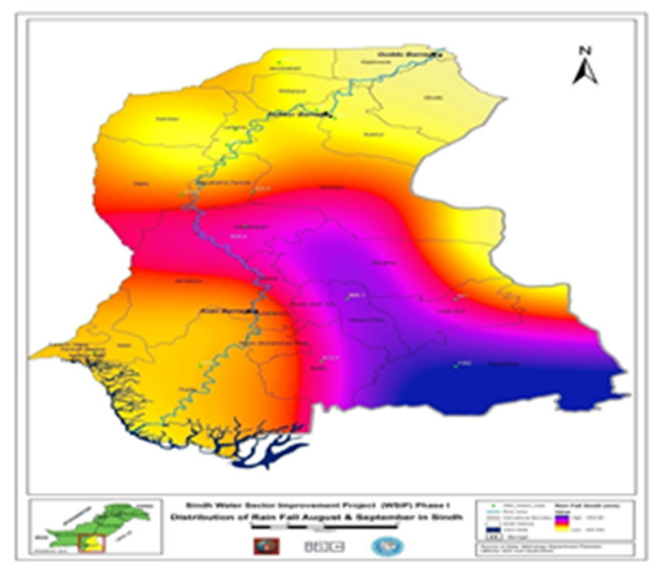

Fig. 1. The map shows the heavy rainfalls in Sindh, Paksitan (C) Sindh Irrigation and Drainage Authority, Hyderabad, Sindh).

\section{DATA COLLECTION}

The research study is based on the annual daily maximum rainfall for Hyderabad and Nawabshah. In this regard, the required data from a period from 1961 to 2011 were collected from Pakistan Meteorological Department (PMD) for statistical analysis [9]. Time series analysis is a time-consuming process, so the statistical software STATISTICA was utilized to do the task with minimum computing cost [14-16]. It is a spread sheet-based statistical analysis software package, which provides the user with a graphical interface, the tools to perform simple analyses such as mean, mode, median, range, trends, and moving mean, all types of distributions and tests like t, F, Z, etc., deviation, regression, ANOVA, etc. It also creates two and three dimensional graphical displays of data. STATISTICA has more than 14,000 statistics functions. The chronological daily maximum rainfall (1961-2011) data for Hyderabad and Nawabshah are shown in Figures 2 and 3, which do not show a definite trend.

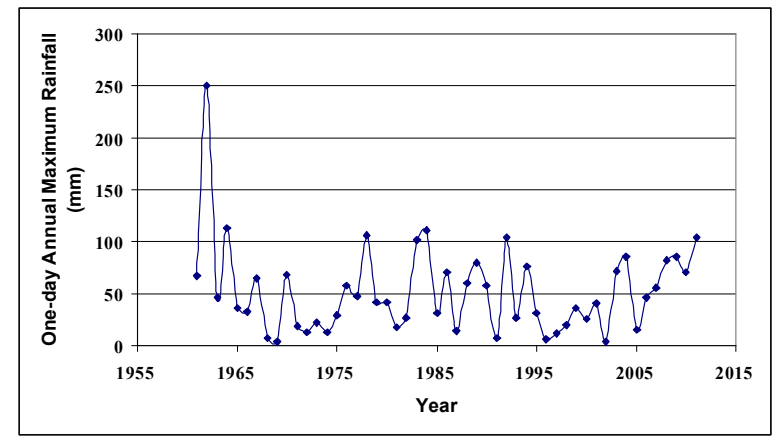

Fig. 2. One-day annual maximum rainfall (1961-2011) for Hyderabad.

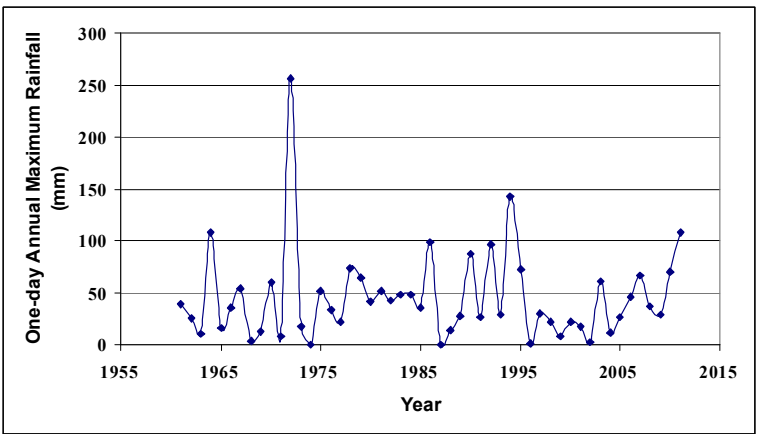

Fig. 3. One-day annual maximum rainfall (1961-2011) for Nawabshah.

The research objective is to study the time series characteristics of one day annual maximum rainfall at Hyderabad and Nawabshah through STATISTICA for smoothing, interpolating, modeling, and future forecasting.

\section{RESUlTS AND DISCUSSION}

\section{A. Rainfall Data Collection}

Figures 4 and 5 display the representation outputs using STATISTICA in terms of deviation of one-day annual maximum rainfall of Hyderabad and Nawabshah respectively from their respective mean rainfall value. These Figures exhibit that the maximum positive deviation is about 200 and more than $200 \mathrm{~mm}$ for Hyderabad and Nawabshah respectively, whereas the maximum negative deviation is less than $50 \mathrm{~mm}$.

\section{B. Basic Statistical Parameters}

The basic statistical parameters maximum, minimum, mean, mode, median standard deviation, and Coefficient of Variance $(\mathrm{CV})$ for the collected data series are described in Table I. 




Fig. 4. Mean deviation analysis of one-day annual maximum rainfall at Hyderabad.

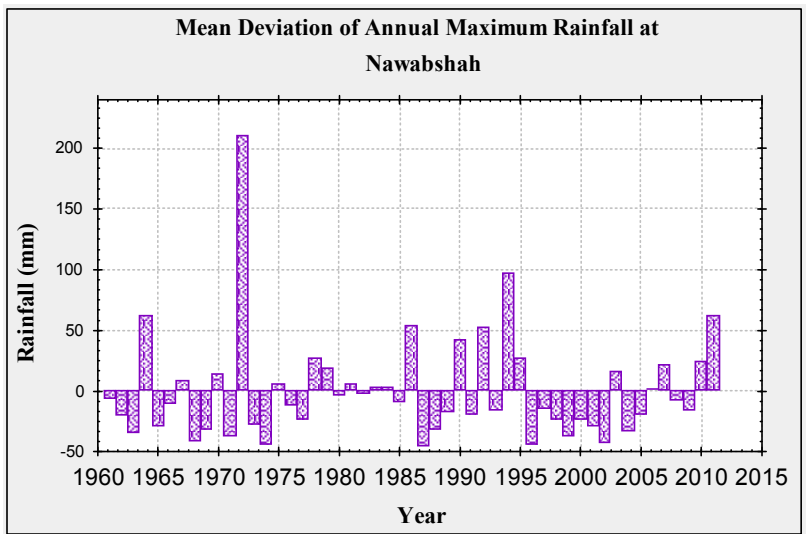

Fig. 5. Mean deviation analysis of one-day annual maximum rainfall at Nawabshah.

TABLE I. BASIC STATISTICAL PARAMETERS FOR ONE DAY MAXIMUM RAINFALL FOR THE PERIOD FROM 1961 TO 2011

\begin{tabular}{|c|c|c|}
\hline Parameter & Hyderabad & Nawabshah \\
\hline Maximum & 250.70 & 256.30 \\
\hline Minimum & 3.0 & 0.0 \\
\hline Median & 41.60 & 35.10 \\
\hline Mode & 12.70 & 22.0 \\
\hline Mean & 51.90 & 45.30 \\
\hline Standard deviation & 42.69 & 43.89 \\
\hline CV & 0.823 & 0.969 \\
\hline
\end{tabular}

For computing standard deviation, $\mathrm{CV}$, or dispersion, it is necessary to conduct Trend and General Trend Analysis. In order to analyze the trends, the data were divided into four groups: 1961-1975, 1976-1990, 1991-2005, and 2006-2011 [17]. The first three periods last 15 years, and the fourth lasts only 6 years. The mean for these grouped data was determined and the difference of the means between the neighboring groups is shown in Table II. The trend of mean is represented in bar charts in Figure 6, whereas the difference of means between neighboring groups is shown in Figure 7. Figure 6 shows that for both study areas the mean is about the same for the 1961-75 and 1976-90 periods, whereas it is decreased for the third period (1991-2005). On the other hand, the mean increased in both cities during the last period. It is to be noted that during the third period (1991-2005) there were droughts in Sindh.

TABLE II. TREND ANALYSIS IN TERMS OF MEAN FOR VARIOUS PERIODS OF THE STUDY AREA

\begin{tabular}{|c|c|c|c|c|c|c|}
\hline \multirow{2}{*}{$\begin{array}{c}\text { Study } \\
\text { area }\end{array}$} & \multirow{2}{*}{\multicolumn{2}{|c|}{ Description }} & Period-I & Period-II & Period-III & Period-IV \\
\hline & & &  & 1976-1990 & \begin{tabular}{|l|l|}
$1991-2005$ \\
\end{tabular} & \begin{tabular}{|c|c|}
$2006-2011$ \\
\end{tabular} \\
\hline \multirow{4}{*}{ 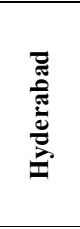 } & \multicolumn{2}{|r|}{ Mean } & 52.23 & 57.51 & 37.45 & 73.70 \\
\hline & \multirow{3}{*}{ 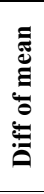 } & $\begin{array}{c}\text { Period-I and } \\
\text { II }\end{array}$ & & 5.27 & & \\
\hline & & \begin{tabular}{|c|} 
Period-II and \\
III
\end{tabular} & & & -20.05 & \\
\hline & & $\begin{array}{l}\text { Period-III } \\
\text { and IV }\end{array}$ & & & & 36.25 \\
\hline \multirow{4}{*}{ 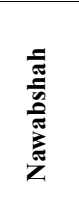 } & \multicolumn{2}{|r|}{ Mean } & 46.64 & 45.73 & 37.90 & 59.53 \\
\hline & \multirow{3}{*}{ 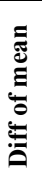 } & $\begin{array}{c}\text { Period-I and } \\
\text { II } \\
\end{array}$ & & -0.91 & & \\
\hline & & \begin{tabular}{|c} 
Period-II and \\
III \\
\end{tabular} & & & -7.83 & \\
\hline & & $\begin{array}{l}\text { Period-III } \\
\text { and IV }\end{array}$ & & & & 21.63 \\
\hline
\end{tabular}



Fig. 6. Variation of mean for the various periods of the study areas.



Fig. 7. Variation of mean for neighboring periods for the study areas.

\section{Linear Trend}

Apart from the above trend, the data were rearranged in descending order and their trend in terms of one-day annual maximum rainfall $(\mathrm{mm})$ was determined in terms of rank. Their best fit trend-line equations along with R-squared values, developed with STATISTICA for Hyderabad and Nawabshah cities are shown in Figures 8 and 9 respectively. These Figures show the outputs in terms of best fit trend-line equations of one-day annual maximum rainfall $(\mathrm{mm})$ value versus the rank 
along with the $\mathrm{R}^{2}$ value. The $\mathrm{R}^{2}$ values for Hyderabad and Nawabshah cities come out as 0.7631 and 0.6883 , which shows the fair linear relationship within the rainfall data.

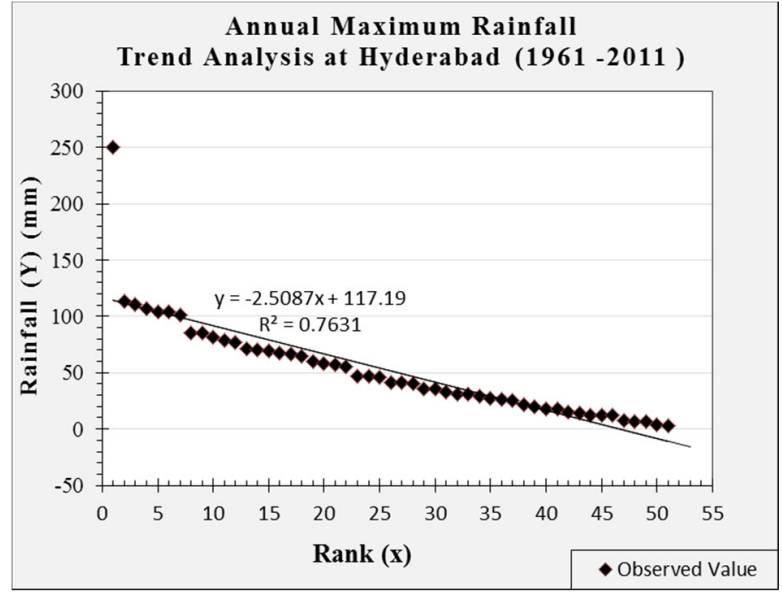

Fig. 8. Linear trend analysis at Hyderabad.

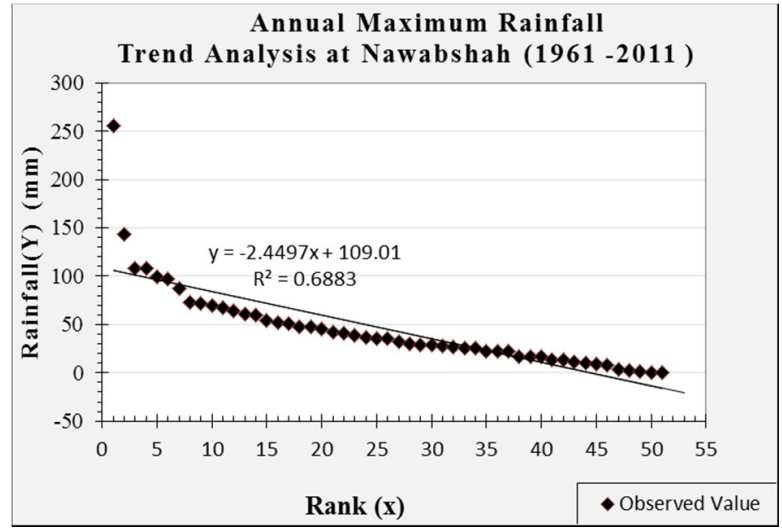

Fig. 9. Linear trend analysis at Nawabshah.

\section{Polynomial Trend and Mean}

\section{1) Polynomial Trend}

Polynomial trend lines have been used to graphically display trends in rainfall data, to analyze problems in relation to the last 51 years rainfall, and to predict future trends. The polynomial trend line is a curved line that shows that the data are fluctuating. Figures 10 and 11 are outputs of the STATISTICA model, which consist of bars with polynomial lines at Hyderabad and Nawabshah respectively. The $\mathrm{x}$-axis represents the years and the y-axis the one day annual maximum rainfall in $\mathrm{mm}$.

\section{2) Moving Mean Smoothing}

The data were also analyzed with regard to moving mean smoothing. A shorter smoothing interval of 3 years has been preferred with secular trend. The smoothed series has a length of 49 years because one value was lost at each end of the series. Figures 12 and 13 show the moving means with secular trend for Hyderabad and Nawabshah. Through these trends, we can predict the future one-day annual maximum rainfall for both study areas.

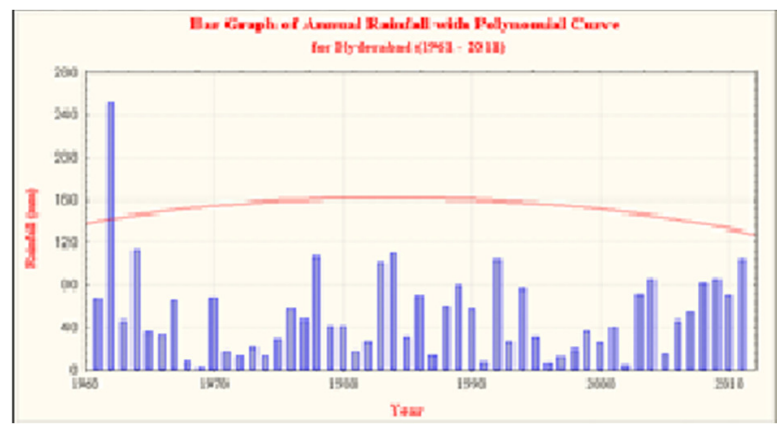

Fig. 10. Bar graph with polynomial trend at Hyderabad.



Fig. 11. Bar graph with polynomial trend at Nawabshah.

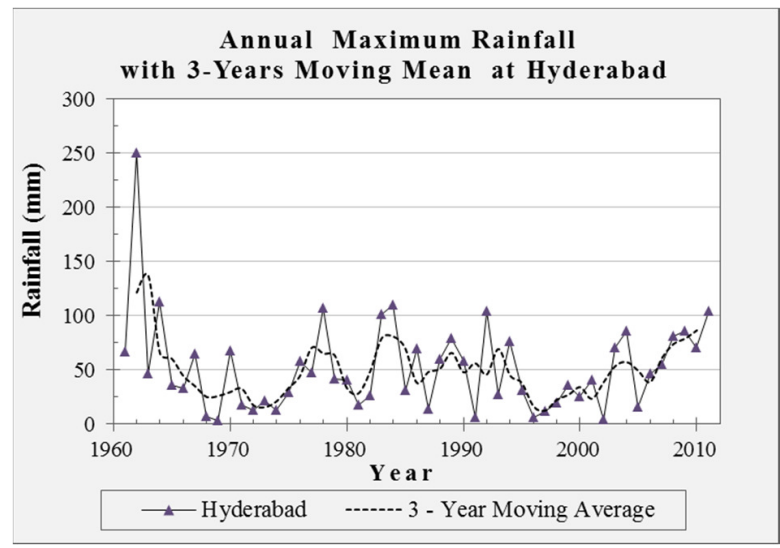

Fig. 12. Moving mean analysis/smoothing for Hyderabad.

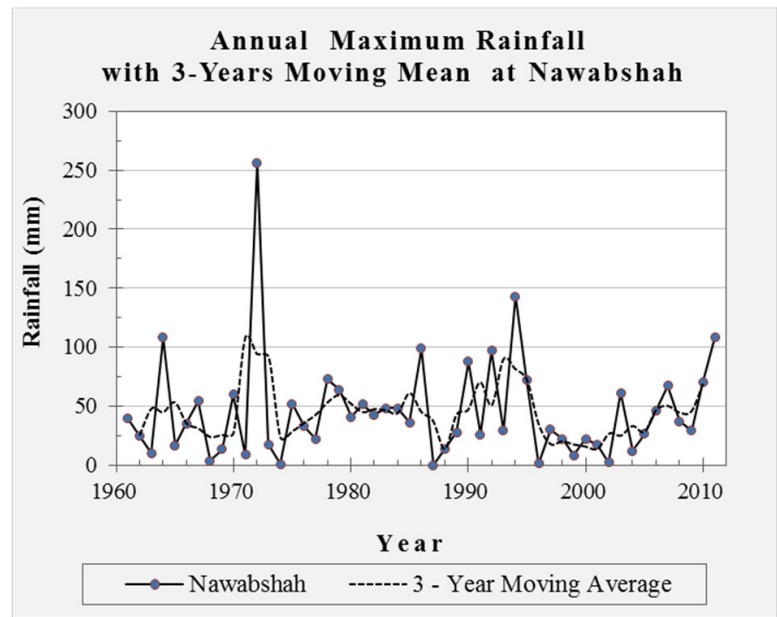

Fig. 13. Moving mean analysis/smoothing for Nawabshah. 


\section{E. Correlation between Rainfall Datat}

The data of day annual maximum rainfall of Hyderabad city were correlated with what of Nawabshah city. The obtained correlation coefficient value is 0.973 , which represents a high degree of rainfall correlation between the two cities. Apparently, the year to year assessment does not match in rainfall performance between these two cities, however, the rainfall data of each station reveal close trend for the rank in ascending order as shown in Figure 14.



Fig. 14. Rainfall correlation between Hyderabad and Nawabshah.

\section{F. Relative Frequency and Return Period}

Relative frequency distribution is more suitable than frequency distribution for data set comparison. The reason is that relative frequencies always fall between 0 and 1 , and hence they provide a standard for comparison. Relative frequency distribution is the ratio of the frequency of a class to the total number of observations. In Figures 15 and 16 the $\mathrm{x}$-axis indicates the return periods and the y-axis the observed rainfall in $\mathrm{mm}$ for the computation of relative frequency.

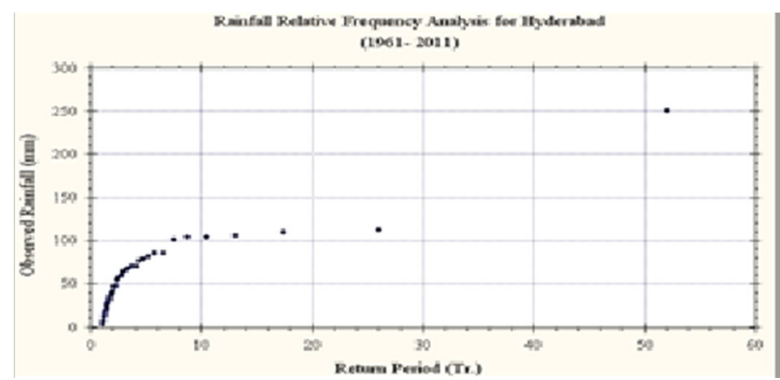

Fig. 15. Relative frequency for Hyderabad.

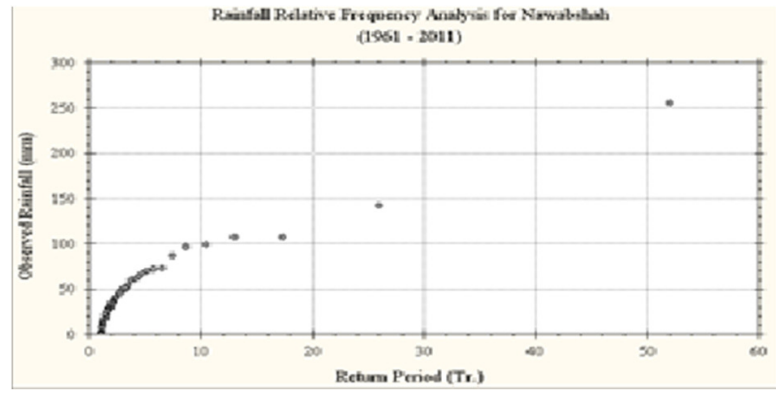

Fig. 16. Relative frequency for Nawabshah
TABLE III. ONE DAY ANNUAL MAXIMUM RAINFALL

\begin{tabular}{|c|c|c|}
\hline \multirow{2}{*}{$\begin{array}{c}\text { Return period } \\
\text { (years) }\end{array}$} & One-day annual maximum rainfall (mm) \\
\cline { 2 - 3 } & Hyderabad & Nawabshah \\
\hline 3 & 67.6 & 50.2 \\
\hline 5 & 84.5 & 68.8 \\
\hline 10 & 104.2 & 98.6 \\
\hline
\end{tabular}

Table III shows the one-day annual maximum rainfalls for the selected return periods of 3,5 , and 10 years for Hyderabad and Nawabshah, computed from Figures 15 and 16. Table III shows that for the selected return periods, the one-day annual maximum rainfall for Hyderabad is more than Nawabshah.

\section{CONCLUSIONS}

It is concluded that the one-day annual maximum rainfall for Hyderabad and Nawabshah time series has a secular trend. This trend in a time series describes the tendency to grow or decline over a long period of time. Hence, secular trend techniques were used through the statistical software STATISTICA. The maximum values of observed rainfall are $250.70 \mathrm{~mm}$ and $256.30 \mathrm{~mm}$, while the minimum values are $3.0 \mathrm{~mm}$ and $0.0 \mathrm{~mm}$, for Hyderabad and Nawabshah respectively. Sudden variation in 51 year's data indicates the change in the rainfall scenario. The mean of 51-year rainfall data at Hyderabad and Nawabshah cities is $51.96 \mathrm{~mm}$ and $45.32 \mathrm{~mm}$ and the standard deviations is $42.693 \mathrm{~mm}$ and $43.896 \mathrm{~mm}$ respectively. The difference between the means and the standard deviations are small, which shows that the data have good consistency. The technique of polynomial trend curved line was used, because the obtained rainfall data are fluctuating which indicates continuous change in rainfall pattern and behavior. Rainfall data were subjected to a moving mean for smoothing with a smoothing interval of 3 years. The smoothed series has a length of 49 years. The moving average smoothing does not provide a forecast equation. The trend has been identified as an almost linear secular trend, so it was necessary to fit a reprehensive equation to the data. The coefficient of correlation between the two datasets is 0.973 . The maximum values at Hyderabad and Nawabshah were recorded in 1962 and 1972 and the minimum values in 1969 and 1987 respectively. The concluded results of rainfall time series revealed that the pattern of change over time and the pattern to forecast and predict future values can be done through the STATISTICA software.

\section{ACKNOWLEDGMENT}

The authors are thankful to the Mehran University of Engineering and Technology and the Irrigation Department of Sindh Irrigation and Drainage Authority, for providing the research facilities.

\section{REFERENCES}

[1] M. A. Mellieres and C. Marechal, Climate Change: Past, Present, and Future. John Wiley \& Sons, 2015.

[2] A. Mahessar, A. Qureshi, G. Dars, and M. Solangi, "Climate Change Impacts on Vulnerable Guddu and Sukkur Barrages in Indus River, Sindh," Sindh University Research Journal (Science Series), vol. 49, no. 1, pp. 137-142, Jan. 2019.

[3] A. A. Mahessar et al., "Flash Flood Climatology in the Lower Region of Southern Sindh," Engineering, Technology \& Applied Science Research, 
vol. 9, no. 4, pp. 4474-4479, Aug. 2019, https://doi.org/10.48084/ etasr.2726.

[4] V. Chow, D. Maidment, and L. Mays, Applied Hydrology, 1st ed. New York, NY, USA: McGraw-Hill, 1988.

[5] S. Das, S. V. Singh, E. N. Rajagopal, and R. Gall, "Mesoscale Modeling for Mountain Weather Forecasting Over the Himalayas," Bulletin of the American Meteorological Society, vol. 84, no. 9, pp. 1237-1244, Sep. 2003, https://doi.org/10.1175/BAMS-84-9-1237.

[6] G. Rasul, Q.-Z. Chaudhry, Z. Sixiong, and Z. Qingcun, "A diagnostic study of record heavy rain in twin cities Islāmābad-Rāwalpindi," Advances in Atmospheric Sciences, vol. 21, no. 6, pp. 976-988, Dec. 2004, https://doi.org/10.1007/BF02915599.

[7] M. Muslehuddin, H. Mir, and N. Faisal, "Sindh Summer (JuneSeptember) Monsoon Rainfall Prediction," Pakistan Journal of Meteorology, vol. 2, no. 4, pp. 91-108, Nov. 2005.

[8] S. Khan and M. Ul-Hasan, "Climate Classification of Pakistan," International Journal of Environment and Pollution, vol. 10, no. 2, pp. 60-71, Jan. 2019.

[9] "Drought Bulletin of Pakistan July-September 2012," National Drought Monitoring Centre, Pakistan Meteorological Department, Islamabad, Pakistan, 2012.

[10] "Pakistan: Monsoon 2011, Situation Report No. 2," OCHA Pakistan, 2011. Accessed: Dec. 12, 2020. [Online]. Available: https://m.reliefweb.int/report/446066.

[11] "Climate of Hyderabad, Sindh," Wikipedia. Jul. 24, 2020, Accessed: Dec. 12, 2020. [Online]. Available: https://en.wikipedia.org/w/ index.php?title=Climate_of_Hyderabad,_Sindh\&oldid=969249380.

[12] "Climate of Nawabshah," Wikipedia. https://en.wikipedia-onipfs.org/wiki/Climate_of_Nawabshah.html (accessed Dec. 12, 2020).

[13] A. A. Mahessar, S. Qureshi, A. L. Qureshi, K. Ansari, and G. H. Dars, "Impact of the Effluents of Hyderabad City, Tando Muhammad Khan, and Matli on Phuleli Canal Water," Engineering, Technology \& Applied Science Research, vol. 10, no. 1, pp. 5281-5287, Feb. 2020, https://doi.org/10.48084/etasr.3269.

[14] I. H. Ibrahim, "Differences between Statistical Software Packages, (SAS, SPSS, and MINITAB), As Applied to Binary Response Variable." 1999.

[15] Statistica Quick Reference. StatSoft, Incorporated, 2007.

[16] D. C. Montgomery, C. L. Jennings, and M. Kulahci, Introduction to Time Series Analysis and Forecasting, 2nd edition. Hoboken, NJ, USA: Wiley-Interscience, 2015.

[17] S. Salma, S. Rehman, and M. A. Shah, "Rainfall trends in different climate zones of Pakistan," Pakistan Journal of Meteorology, vol. 9, no. 17, pp. 37-47, 2012. 